\title{
DEMAND \& DEFECTIVE GROWTH PATTERNS: THE ROLE OF THE TRADABLE AND NON-TRADABLE SECTORS IN AN OPEN ECONOMY
}

\author{
Sandile Hlatshwayo \& Michael Spence
}

Online Appendix

\section{Methodology}

In order to proxy the tradability of an industry, we rely on Jensen and Kletzer's (2005) measures of geographical concentration of industries using locational Gini coefficients, which are based on employment measures. The intuition is as follows: non-tradable goods and services (e.g. dentists and cement suppliers) tend to be located everywhere, whereas tradable goods and services (e.g. financial services and manufacturing production) tend to be concentrated geographically. The latter's geographical concentration can be explained via a number of mechanisms, namely the gains from economies of scale in tradable industries (Helpman and Krugman 1985).

To avoid classifying non-tradable industries that are concentrated due to outsized, concentrated demand as tradable, Jensen and Kletzer allow for non-tradable industries that are inputs of downstream industries to follow the geographical distribution of said downstream industries (rather than relying on a measure of income for demand). The first component of the Gini measure is industry demand share, which measures the concentration of demand for industry $\mathrm{i}$ in region $\mathrm{p}$ and is calculated as follows:

$$
\text { Industry Demand Share }(I D S)_{i, p} \equiv \sum_{j}\left(\frac{Y_{i, j}}{Y_{i}} \times \frac{\ln E M P_{j, p}}{\ln E M P_{j}}\right)
$$

Where $Y_{i, j}$ is output of industry $i$ used by industry $j$; $Y_{i}$ is total output of industry $i$; EMP $_{j, p}$ is industry $\mathrm{j}$ employment in region $\mathrm{p}$; and $\mathrm{EMP}_{\mathrm{j}}$ is total industry $\mathrm{j}$ employment.

The industry demand shares (IDSs) are then used as an input to calculate locational Gini coefficients by industry:

$$
\operatorname{Gini}(G)_{i}=\left|1-\sum_{p}\left(\sigma Y_{i, p-1}+\sigma Y_{i, p}\right) \times\left(\sigma I D S_{i, p-1}-\sigma I D S_{i, p}\right)\right|
$$

Where p's index regions, sorted by share of industry employment; $\sigma Y_{i, p-1}$ is the cumulative share of industry i employment in the region (p-1) with the next lowest share of industry employment; $\sigma Y_{i, p}$ is the cumulative share of industry i employment in region p; $\sigma \operatorname{IDS}_{\mathrm{i}, \mathrm{p}-1}$ is the cumulative share of industry $i$ IDS in the region (p-1) with the next lowest share of industry IDS; and $\sigma$ IDS $_{i, p}$ is the cumulative share of industry $i$ IDS in the region $p$.

A low Gini corresponds to a highly non-tradable industry, while a high Gini corresponds to a highly tradable industry. ${ }^{1}$ Admittedly, these measures pick up domestic tradability more than

\footnotetext{
${ }^{1}$ Using their continuous measure of tradability, we classed Gini class 1 (below .1) as non-tradable proportions and Gini class 2 and 3 (above .1) as tradable proportions. These measures were constructed using the 1999 input output use tables from the Bureau of Economic Analysis and the 2000 Decennial Census of Population Public Use Micro Sample (PUMS).
} 
internationally tradability. To that end, we make some value judgments about the classifications of certain industries as internationally tradable. ${ }^{2}$

Applying the industry tradable/non-tradable splits, we then use seasonally-adjusted employment data by industry from the Bureau of Labor Statistics' Current Employment Statistics

(supplemented with Bureau of Economic Analysis data for the agricultural industry) and valueadded data by industry from the Bureau of Economic Analysis's data. The data for both employment and value added are at the two-digit level.

One weakness of this approach is that we assume tradability to be static overtime. For industries like manufacturing and agriculture that have always been wholly tradable, this point is not relevant. For industries that have benefitted greatly from the information technology and communication revolution (e.g. consulting, radiology, and payroll services), this outage is more worrying. However, most of these industries are classed as largely tradable already. Also, even among professional service industries that are increasing in tradability, only a small number of clientele are taking advantage of the ability to source services like architectural, computer systems design, and accounting services from abroad. Thus, in the aggregate, we feel our approach is robust. The industry splits are below.

\section{Industry Splits}

\begin{tabular}{|l|c|c|}
\hline Percent of Industry & Non-tradable & Tradable \\
\hline Accommodation and food services & 100 & 0 \\
\hline Administrative and waste services & 89.8 & 10.2 \\
\hline Agriculture, forestry, fishing, and hunting & 0 & 100 \\
\hline Arts, entertainment, recreation & 90 & 10 \\
\hline Construction & 100 & 0 \\
\hline Educational services & 98.89 & 1.11 \\
\hline Finance and insurance & 32.05 & 67.95 \\
\hline Government & 90 & 10 \\
\hline Health care and social assistance & 97.8 & 2.2 \\
\hline Information & 34.1 & 65.9 \\
\hline Manufacturing I & 0 & 100 \\
\hline Manufacturing II & 0 & 100 \\
\hline Manufacturing III & 0 & 100 \\
\hline Mining & 0 & 100 \\
\hline Other services & 100 & 0 \\
\hline Professional Services & 39.2 & 60.8 \\
\hline Real estate and rental and leasing & 100 & 0 \\
\hline Retail trade & 85.185 & 14.815 \\
\hline Transportation and warehousing & 0 & 100 \\
\hline Utilities & 40 & 60 \\
\hline Wholesale trade & 100 & 0 \\
\hline
\end{tabular}

\footnotetext{
${ }^{2}$ Legal services is once such example of an industry that appears domestically tradable, but tends to not be internationally tradable.
} 


\section{Drivers and Drags of the Post-Crisis Recovery with Industry Detail}

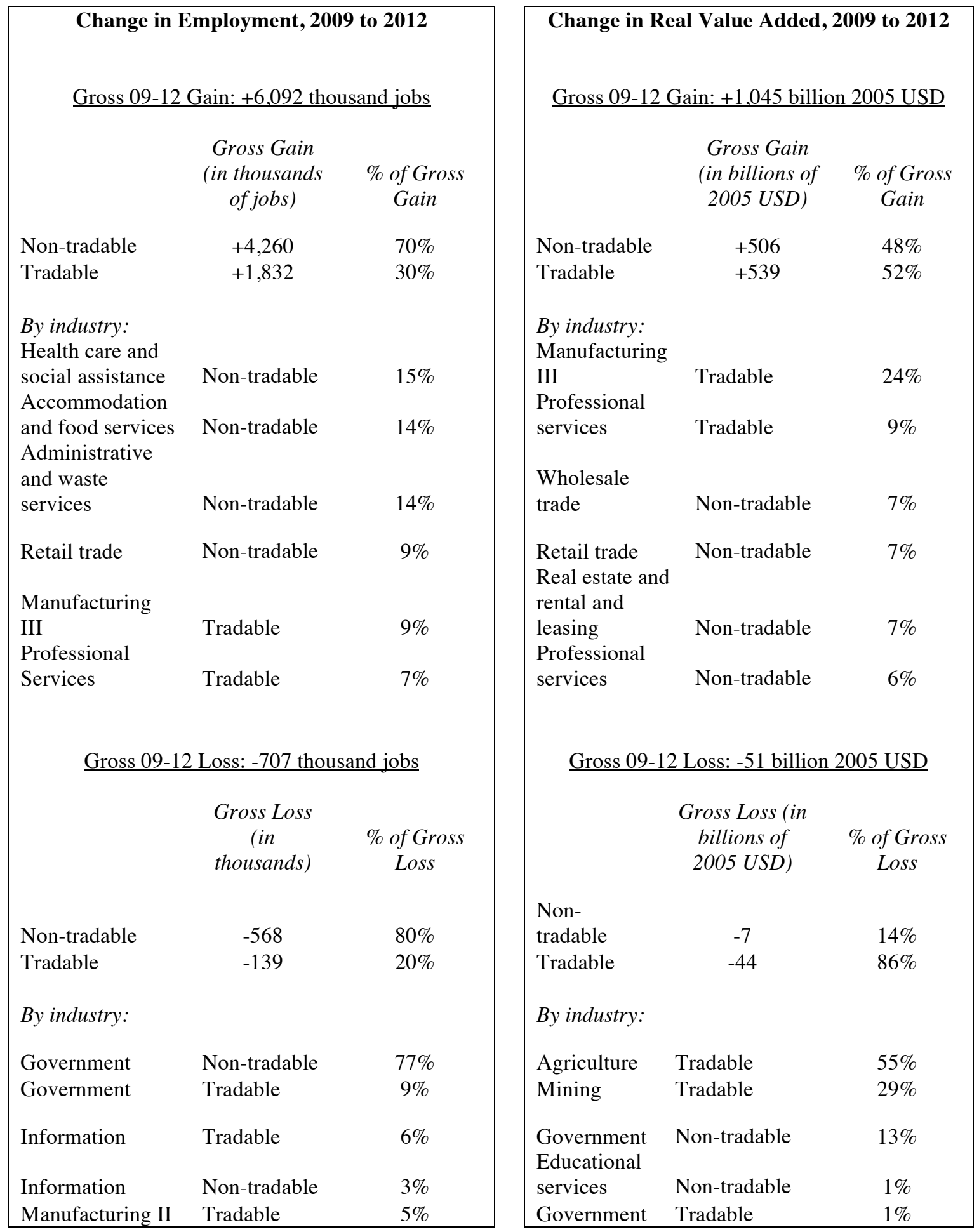

